\title{
Diversity of Small Indigenous Freshwater Ornamental Fish under Genus Puntius from Purba Medinipur, Paschim Medinipur and Jhargram Districts of West Bengal, India
}

\author{
Godhuli Sit, Arun Jana, Angsuman Chanda* \\ Natural Science Research Centre, Raja N.L. Khan Women's College (Autonomous), Vidyasagar University, India
}

Received April 8, 2020; Revised April 29, 2020; Accepted June 16, 2020

Copyright $\bigcirc 2020$ by authors, all rights reserved. Authors agree that this article remains permanently open access under the terms of the Creative Commons Attribution License 4.0 International License

\begin{abstract}
The main objective of the present study is the investigation of small indigenous freshwater ornamental fish diversity of Purba Medinipur, Paschim Medinipur and Jhargram districts of West Bengal, India and emphasis has been given to their ornamental value and local abundance. Present study is restricted only on the fish species belonging to the genus Puntius. During the study, small freshwater fish species has been surveyed covering all blocks of the three districts under study. Specimens have been collected from different freshwater ecosystems like rivers, ponds, beels etc. and are preserved and identified. It has been observed that the study area represents the existence of nine species of indigenous freshwater small fishes under genus Puntius. Among the recorded nine species, two species, namely Puntius guganio (Hamilton-Buchanan, 1822) and Puntius gelius (Hamilton-Buchanan, 1822) are being found for the first time from the study site. All the nine species are potential to be regarded as ornamental fish. A detail distributional data has been provided for all the species of the genus from the study area. Therefore, present study will highlight the local macro-faunal diversity of the freshwater fish species under genus Puntius as well as ability to become ornamental fish for aquarium keeping. Record of two small fish species from the freshwater ecosystem of the study area is the new addition to the local fish faunal diversity.
\end{abstract}

Keywords Puntius, Record, Ornamental, Fish

\section{Introduction}

The genus Puntius Hamilton-Buchanan (1822) is a large group of small fishes. It is a complex genus, which exhibit high degree of variability in colour pattern, size and habitat such as ditches, pond, rivers and hill stream. The status of Puntius is controversial; the delimitation and nomenclature validity of the genus have remained unsettled (Hora \& Mukerjii, 1934; Smith, 1945; Mayers, 1960). The genus Puntius has long been recognized as a "catchall" genus for a variety of small tropical Asian cyprinids whose inter-relationships (Kottelat, 1999). They have a good food and ornamental value due to presence of definite amount of carbohydrate, protein, minerals, etc., and different color, spot, band and behavior are attracted aquarist.

The genus Puntius is represented by a large number of species in the Asian tropics (Hamilton, Buchanan, 1822). The cyprinids species Puntius are small indigenous species (SIS) used to be abundantly available in rivers, streams, ponds, beels, ditches, and floodplains in the past in the South Asian countries (Shanta kumar and Viswanath, 2006). Abundant diversity of Puntius having 53 species is distributed throughout India, Nepal, Bangladesh, Srilanka, Mayanmar, Thailand, Malaya Archipelago and Southern China (Jayaram, 1991).

Moglekar, et al, (2017), enlisted 6 species of genus Puntius, namely Puntius ticto (Hamilton, 1822), Puntius chola (Hamilton, 1822), Puntius sophore (Hamilton, 1822), Puntius puntio (Hamilton, 1822), Puntius terio (Hamilton, 1822), Puntiu svitatus (Day, 1865) by the help of previous existing fish species checklist (2003-2015) from different districts and rivers of West Bengal. Paul and Chanda (2017), and Kisku et al., (2017) enlisted 3 species of genus Puntius, namely Puntius ticto (Hamilton, 1822), Puntius chola (Hamilton, 1822), Puntius sophore (Hamilton, 1822) from Paschim Medinipur district. Different scientists reported different fish diversity from the study area but none reported the species of the genus Puntius separately from the study area. Therefore, the 
present report is an attempt towards the comprehensive study of Puntius species diversity of Purba Medinipur, paschim Medinipur \& Jhargram district of West Bengal, India.

\section{Study Site}

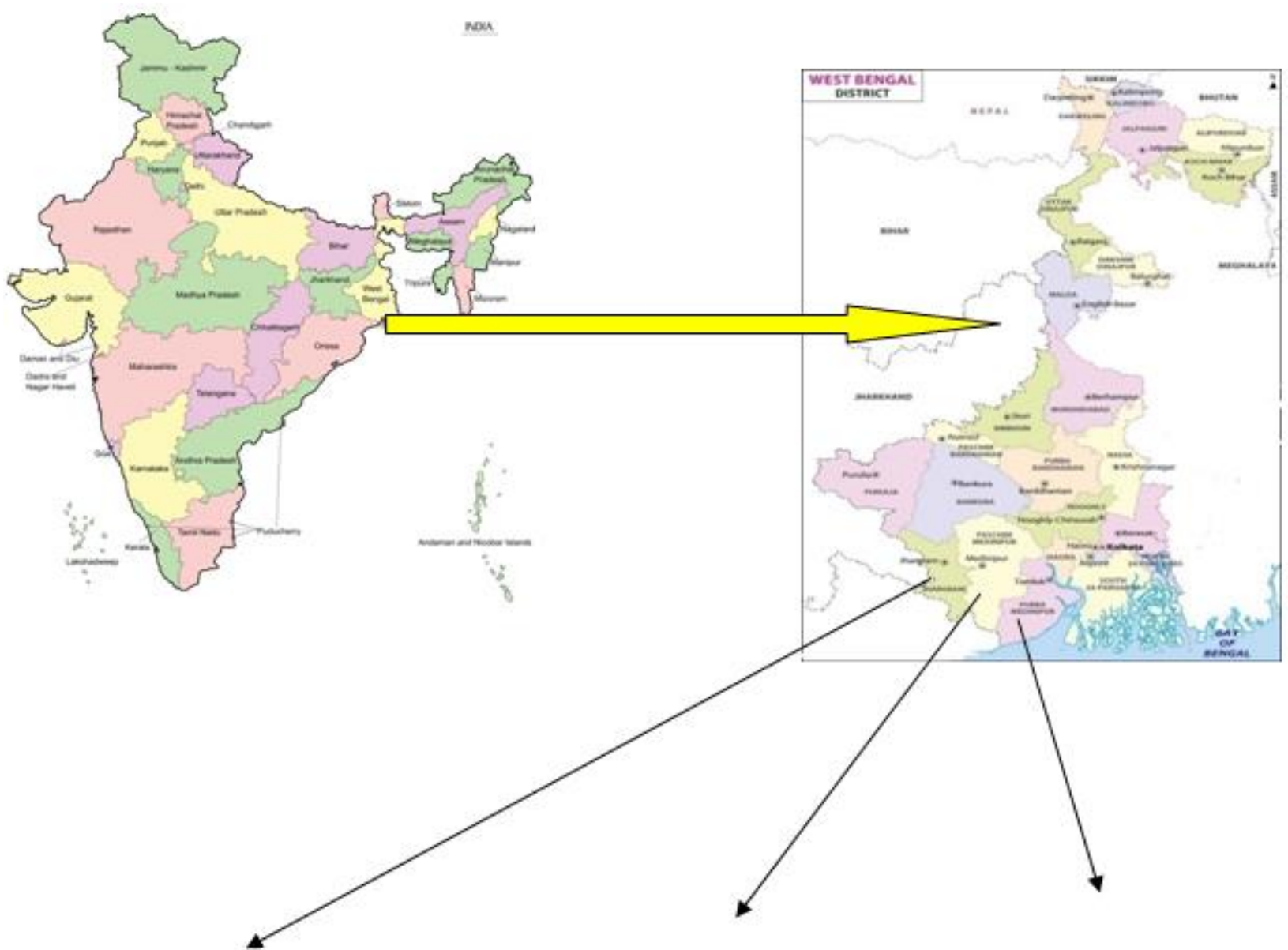

The study sites are Jhargram $\left(21^{\circ} 52^{\prime}-22^{\circ} 48^{\prime} \mathrm{N} ; 86^{\circ}\right.$ $\left.34^{\prime}-87^{\circ} 20^{\prime} \mathrm{E}\right)$, Paschim Medinipur $\left(21^{\circ} 45^{\prime}-22^{\circ} 57^{\prime} \mathrm{N}\right.$; $\left.87^{\circ} 03^{\prime}-87^{\circ} 53^{\prime} \mathrm{E}\right)$ and Purba Medinipur $\left(21^{\circ} 38^{\prime}-22^{\circ}\right.$ $31^{\prime} \mathrm{N} ; 87^{\circ} 17^{\prime}-88^{\circ} 12^{\prime} \mathrm{E}$ ) districts are located in the laterite belt of West Bengal. Climatic conditions under the influence of South-West and North-East monsoon.

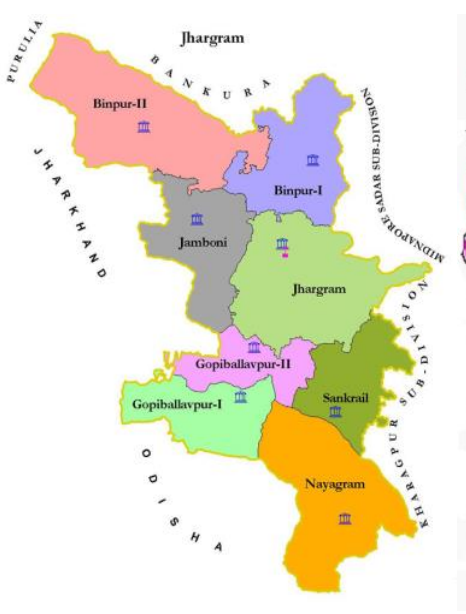

JHARGRAM

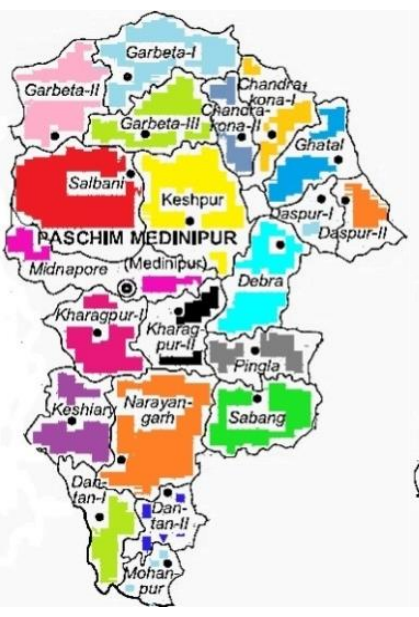

PASCHIM MEDINIPUR

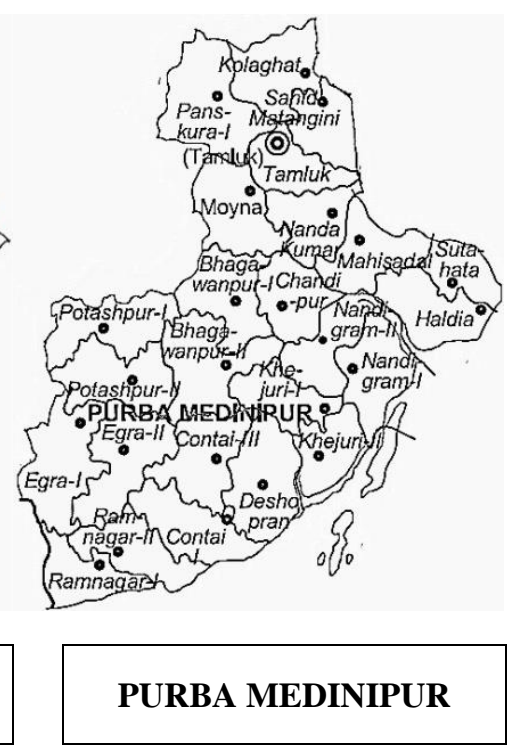


Table 1. Block wise distribution of different species under genus Puntius found in study area. Abbreviations: LC $=$ Least Concern; NE $=$ Not Evaluated; VU = Vulnerable; High = Found in maximum blocks $(>15$ blocks $)$; Very low = Found only in one or two blocks; Medium $=$ Found more than 2 but less than 15 blocks.

\begin{tabular}{|c|c|c|c|c|}
\hline $\begin{array}{l}\text { Sl. } \\
\text { No. }\end{array}$ & Species Name & $\begin{array}{l}\text { Distribution } \\
\text { (block wise) }\end{array}$ & $\begin{array}{l}\text { IUCN } \\
\text { status }\end{array}$ & $\begin{array}{l}\text { Abundance } \\
\text { In study area }\end{array}$ \\
\hline 1 & $\begin{array}{c}\text { Puntius chola } \\
\text { (Hamilton-Buchanan,1822) }\end{array}$ & $\begin{array}{l}\text { Jhargram: Binpur-I,Jamboni,Gopi-I\&II, Sankrail,Jhargram } \\
\text { PaschimMedinipur: Daspur-I, Debra, Garbeta-II\&III, Sabang, } \\
\text { Pingla, Salboni, Keshpur } \\
\text { PurbaMedinipur: Egra-I\&II, Bhawanpur-I \& II, Contai-I\&III, } \\
\text { Mahisadal, Moyna, Nandigram-I, Panskura, Potaspur-I, } \\
\text { Potaspur-II, Tamluk }\end{array}$ & $\mathrm{LC}$ & High \\
\hline 2 & $\begin{array}{l}\text { Puntius conchonius } \\
\text { (Hamilton-Buchanan, } \\
\text { 1822) }\end{array}$ & $\begin{array}{l}\text { Jhargram: Binpur-II, Gopi-I } \\
\text { PaschimMedinipur: Daspur-I, Chandrakona-I, Sabang, } \\
\text { Midnapore } \\
\text { PurbaMedinipur: Bhawanpur-I, Mahisadal, Moyna, } \\
\text { Nandigram-I }\end{array}$ & $\mathrm{LC}$ & Medium \\
\hline 3 & $\begin{array}{c}\text { Puntius ticto } \\
\text { (Hamilton-Buchanan,1822) }\end{array}$ & $\begin{array}{l}\text { Jhargram: Binpur-I, Gopi-I\&II } \\
\text { PaschimMedinipur: Ghatal, Debra, Sabang } \\
\text { PurbaMedinipur: Mahisadal, Moyna }\end{array}$ & $\mathrm{LC}$ & Medium \\
\hline 4 & $\begin{array}{c}\text { Puntius terio } \\
\text { (Hamilton-Buchanan, } \\
1822 \text { ) }\end{array}$ & $\begin{array}{l}\text { Jhargram: Gopi-I } \\
\text { PaschimMedinipur: Midnapore }\end{array}$ & $\mathrm{LC}$ & Very low \\
\hline 5 & $\begin{array}{c}\text { Puntius gelius } \\
\text { (Hamilton-Buchanan, } \\
\text { 1822) }\end{array}$ & PurbaMedinipur: Nandigram-I & $\mathrm{LC}$ & Very low \\
\hline 6 & $\begin{array}{c}\text { Puntius guganio } \\
\text { (Hamilton-Buchanan, } \\
\text { 1822) }\end{array}$ & Jhargram: Gopiballavpur-I & $\mathrm{NE}$ & Very low \\
\hline 7 & $\begin{array}{c}\text { Puntius phutunio } \\
\text { (Hamilton-Buchanan,1822) }\end{array}$ & $\begin{array}{l}\text { Jhargram: Gopi-I\&II, Binpur-II, Sankrail, Nayagram } \\
\text { PaschimMedinipur: Daspur-I, Ghatal, Chandrakona-I } \\
\text { PurbaMedinipur: Mahisadal, Nandigram-I, Bhawanpur-I \&II, } \\
\text { Tamluk }\end{array}$ & $\mathrm{LC}$ & Medium \\
\hline 8 & $\begin{array}{c}\text { Puntius sarana } \\
\text { (Hamilton-Buchanan, } \\
\text { 1822) } \\
\end{array}$ & $\begin{array}{l}\text { PaschimMedinipur: Ghatal } \\
\text { Jhargram: Gopi-I }\end{array}$ & VU & Very low \\
\hline 9 & $\begin{array}{c}\text { Puntius sophore } \\
\text { (Hamilton-Buchanan,1822) }\end{array}$ & $\begin{array}{l}\text { Jhargram: Binpur-I\&II, Gopi-I, Sankrail } \\
\text { PaschimMedinipur: Midnapore, Sabang, Garbeta -I \&III, } \\
\text { Salboni, Keshpur, Daspur-I, Khargpur-I\&II, Keshiari, } \\
\text { Narayangarh, Mohanpur } \\
\text { PurbaMedinipur: Egra-I\&II, Contai-I\&III, Mahisadal, Moyna, } \\
\text { Nandigram-I, Panskura, Potaspur-I, Potaspur-II, Bhawanpur-I } \\
\text { \&II, Tamluk }\end{array}$ & $\mathrm{LC}$ & High \\
\hline
\end{tabular}

\section{Methods}

The specimens were collected from different rivers, ponds, beels, markets of different blocks of Purba Medinipur, Paschim Medinipur and Jhargram district of West Bengalfrom July 2019 to January 2020. After collection, the specimens have immediately preserved by $4 \%$ formaldehyde and brought to laboratory of the department of Zoology (UG \& PG) of Raja N. L. Khan Women's College (Autonomous). Finally, specimens were washed and preserved $6 \%$ formaldehyde in a labelling container. The specimens were studied morphologically such as size, color, band, fin number, fin shape, fin rays, scale number etc. All measurement of fish was made in metric system followed by Talwar and Jhingran, (1991); Jayaram, (1999), Jayagram, (2010) \& www. Fishbase.org. Distribution of the species has been recorded (Table- 1).

\section{Results}

\section{Genus Puntius Hamilton-Buchanan, 1822}

Hamilton (1822) created the genus based on the Cyprinus sophore as type species for the genus. 57 species of Genus Puntius have been found in the world and 35 species were found in India. A brief history of the genus with special reference to Indian contribution has been given below.

1999 Puntius Menon, Records of the Zoological Survey of India, Occasional Paper No. 175: i-xxix + 1-366; Vishwanath \& Laisram, 2004, Journal of the Bombay Natural History Society.101 (pt 1): 138-140; S. Mirza, 2003, Pakistan J. Zool. Supplm. Series No. 3.

Type species: Cyprinus sophore Hamilton, 1822, Edinburgh \& London, i-vii + 1-405. 
Type locality: Pond and rivers in Gangetic provinces.

\section{Diagnosis of the Genus:}

Body is short, deep \& compressed. Head short and abdomen rounded. Mouth is anterior or inferior. Upper jaw sometime protractile, lips are thin. Jaw without any knob at the symphysis. Barbells when present are four or two in number. Dorsal fin inserted nearly opposite of pelvic fin with 9-13 rays. Caudal fin forked. Lateral line complete or incomplete with 20-47 scales.

\section{Species 1: Puntius chola (Hamilton-Buchanan, 1822)}

Puntius chola was originally described as Cyprinus chola (Hamilton-Buchanan, 1822) from north-eastern parts of Bengal. A brief history of the species with special reference to Indian contributions has been given below.

1822 Cyprinus titius Hamilton, An account of the fishes found in the river Ganges and its branches. Edinburgh \& London. I-vii + 1-405, Pls. 1-39.

1878 Barbus chola Day, Fishes of India: 571, pl.142, fig. 4; Day, 1889, Fauna Br. India, Fishes, 1:317.

1878 Barbus tetrarupagus (McClelland) Day, Fishes of India: 572, pl.142, fig. 6; Day, 1889, Fauna Br. India, Fishes, 1:318.

1999 Puntius chola Menon, Records of the Zoological Survey of India, Occasional Paper No.175: i-xxix + 1-366.

Type species: Cyprinus chola Hamilton-Buchanan, 1822, Fishes of Ganges: 312, 289.

Type locality: North-eastern parts of Bengal.

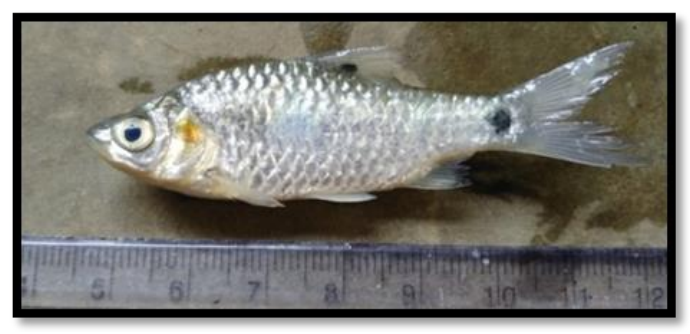

Figure 1. Puntius chola (Hamilton-Buchanan, 1822)

Diagnosis of Species (Fig-1): Body deep and compressed. The head is small, and narrower than the body. At each corner of the mouth is a tendril. The mouth is small, and descends obliquely. Maxillary barbells are one pair. Lateral line is complete with a slight curve from the shoulder with 24-28 scales, Pre-dorsal scales 10 to 12 , circumpeduncular scales 14 , pre-pelvic scales 11 , pre-anal scales 19; total length: $5-12 \mathrm{~cm}$.

Fin formula- D iii 8; P i 14; V i 8; A ii 5.

Ornamental Value: $P$. chola can be considered as ornamental fish because of its silvery body color with a large black blotch at the base of caudal peduncle; another black blotch at the base of dorsal fin, operculum with a golden to reddish golden spot and some specimen possess a light red mark started behind from operculum to caudal peduncle which makes the fish more attractive and popular.

\section{Species 2: Puntius conchonius (Hamilton-Buchanan, 1822)}

Puntius conchonius was originally described as Cyprinus conchonius (Hamilton-Buchanan, 1822) from fishes of Ganges. A brief history of the species with special reference to Indian contributions has been given below.

1822 Cyprinus conchonius Hamilton-Buchnan, Fishes of Ganges:317,389

1878 Barbus conchonius Day, Fishes of India: 576, pl.143, fig.7; Day, 1889, Fauna Br. India, Fishes, 1:325; Sterba, 1967, Freshwater Fishes of the World: 284, fig. 320 .

1982 Puntius conchonius Jayaram et al., Rec. zool. Suru. India Occ. Paper, (36):54, fig. 10

1988 Puntius conchonius khagariansis Srivastava and Munshi, Natural History of Fishes and Systematics of Freshwater Fishes of India:186

Type species: Cyprinus conchonius, Hamilton-Buchnan, 1822, Fishes of Ganges: 317,389

Type locality: Ponds of northeast Bengal; Kosi River and Ami River, Bihar.

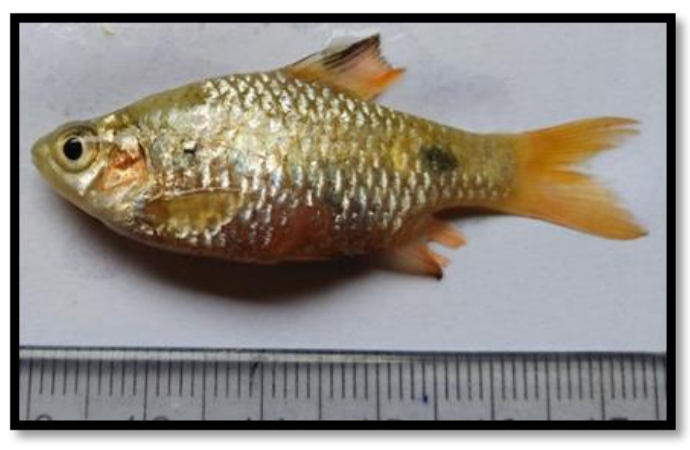

Figure 2. Puntius conchonius (Hamilton-Buchanan, 1822)

Diagnosis of Species (Fig-2): Body deep and compressed, its depth 2.2 to 2.5 times in standard length. Head is 4.1 to 4.5 times in standard length. Mouth is moderate; no barbless. Dorsal fin inserted equidistant between tip of snout and base of caudal fin; its last unbranched ray osseous, moderately strong and serrated. Scales medium; lateral line incomplete, ceases after $10^{\text {th }}$ to $13^{\text {th }}$ scales, 24 to $26 \mathrm{sc}$ ales in longitudinal series, total length: $5.5-9 \mathrm{~cm}$. 
Ornamental Value: It has shiny olive-green back, silvery flanks and belly, tinged with reddish color and a black golden yellow bordered. Blotch present at the caudal peduncle easily eye catching; therefore, it can be considered as Ornamental fish.

\section{Species 3: Puntius ticto (Hamilton-Buchanan, 1822)}

Puntius ticto was originally described as Cyprinus ticto Hamilton-Buchanan (1822). A brief history of the species with special reference to Indian contributions has been given below.

1822 Cyprinus ticto Hamilton-Buchanan, Fishes of Ganges: 314, 398, pl. 8, fig. 87: Murthy, 1977, Proc. Indian acad. Sci., 85B (3):130

1865 Puntius punctatus Day, Proc. Zool. Soc. Lond::302; Hora, Misra and Malik, 1939, Rec. Indian Mus., 41(3): 263.

1878 Barbus ticto Day, Fishes of India: 576, pl.144, fig. 7; Day, 1889, Fauna Br. India, Fishes, 1:325.; Hora and Misra, 1938, J. Bombay nat. Hist. Soc., 40(1): 28, fig. 3.

2012 Pethia ticto Pethiyagoda et al.,Ichthyol. Explor. Freshwaters, Vol. 23, Nr. 1, Seiten 69-95.

Type species: 1822. Cyprinus ticto Hamilton-Buchanan, Fishes of Ganges, 314, 398, pI. 8, fig. 87.

Type locality: South eastern parts of Bengal.

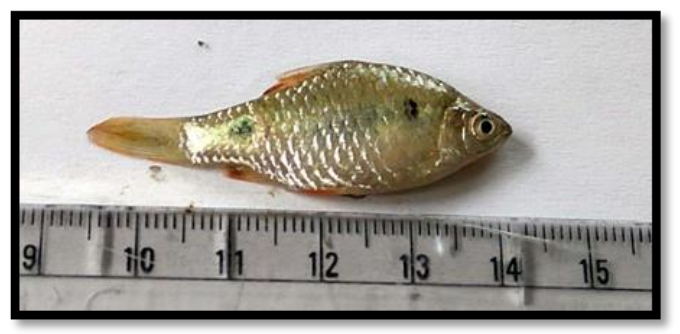

Figure 3. Puntius ticto (Hamilton-Buchanan, 1822)

\section{Diagnosis of Species (Fig-3):}

Mouth is small and terminal, barbells are absent. Dorsal fin inserted slightly posterior to the origin of pelvic fin. Lateral line generally incomplete with 23-25 scales in longitudinal series. A long transverse blotch is present in the above of pectoral fin and second blotch present in the above of anal fin end; total length: $5-6 \mathrm{~cm}$.

Fin formula- D iii-iv 8; P 13-15; V i 8; A ii-iii 5.

Ornamental Value: $P$. ticto possess translucent shining silvery to greenish-gray body, a small black humeral spot present in the above of pectoral fin and second one present with anterior golden edged in the above of anal fin end, can made the fish very popular in aquarium.

\section{Species 4: Puntius terio (Hamilton-Buchanan, 1822)}

Puntius terio was originally described as Cyprinus terio (Hamilton-Buchanan, 1822) from north -east Bengal. A brief history of the species with special reference to Indian contributions has been given below.

1822 Cyprinus terio Hamilton-Buchanan, Fishes of Ganges: 313, 389.

1878 Barbus terio Day, Fishes of India:580, pl.144, fig. 3; Day, 1889, Fauna Br. India, Fishes, 1:330.

2003 Cyprinus terio Ataur Rahman,Zoological Society of Bangladesh, Dhaka. i-xviii + 1-394.

Type species: Cyprinus terio Hamilton, 1822, Fishes of Ganges, 313, 389.

Type locality: North-eastern Bengal.

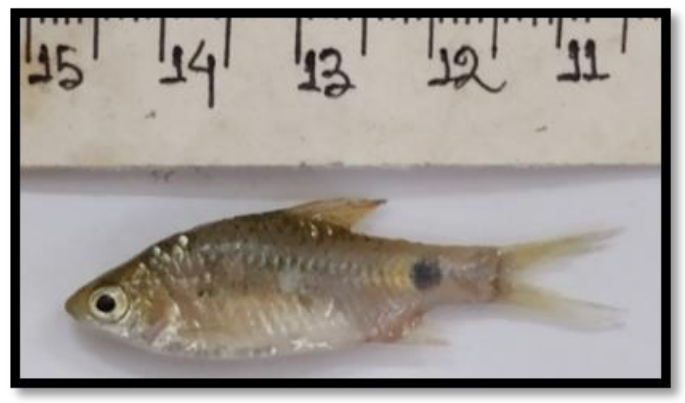

Figure4. Puntius terio (Hamilton-Buchanan, 1822)

Diagnosis of Species (Fig-4): Body elongate, deep and compressed. Body depth is 2.4 times in standard length. Head length is 3.3-3.8 times in standard length. Eye diameter is 2.75- 3 times of head length. Barbells are absent. Lateral line incomplete with 22-23 scales in longitudinal series. Over anal fin a large blotch present. Dorsal fin has numerous dark spots and streaks. Body color in dorsal side is metallic green and in ventral side is whitish with light reddish, total length: $5-8 \mathrm{~cm}$.

Fin formula- D iii 8; P 14-15; V 9; A 7-8.

Ornamental Value: P. terio has greenish-silvery body with a large round golden-edged black blotch over anal fin, dorsal fin sometimes with dark spot, has considered the fish as ornamental.

\section{Species 5: Puntius gelius (Hamilton-Buchanan, 1822)}

Puntius gelius was originally described as Cyprinus gelius (Hamilton-Buchanan, 1822) from north -east Bengal. A brief history of the species with special reference to Indian contributions has been given below.

1822 Cyprinus gelius Hamilton-Buchanan, Fishes of Ganges: 320, 390, Pl. 145, fig. 3

1878 Barbus gelius Day, Fishes of India: 577, pl. 145, fig. 3; day, 1889, Fauna Br. India, Fishes, 1: 327 


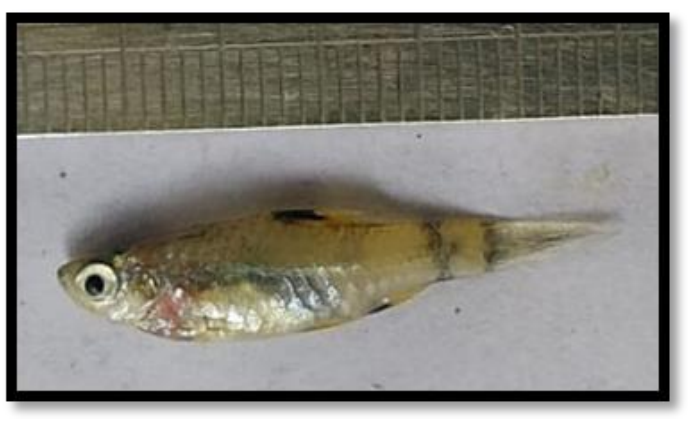

Figure 5. Puntius gelius (Hamilton-Buchanan, 1822)

Type species: Cyprinus gelius Hamilton-Buchanan, 1822, Fishes of Ganges: 320, 390, Pl. 145, fig. 3

Type locality: Ponds of north-east Bengal

\section{Diagnosis of Species (Fig-5):}

Elongate body moderately compressed. Mouth small, slightly oblique with no barbells and upper jaw slightly longer. Last unbranched ray of dorsal fin is osseous and serrated. Dorsal fin originates nearer to snout tip than the caudal base. Pelvic fine originate below that of dorsal and pectoral as long as head excluding snout. Scales are fairly small and lateral line incomplete, total length: $2.5-4 \mathrm{~cm}$.

Fin formula: D ii-iii 8; P i 14; V i 8; A iii 5

Ornamental Value: $P$. gelius can be considered as ornamental fish because of its body color which appears as golden along with a dark band over the tail anterior to the caudal fin another dark band present at the caudal peduncle, dorsal fin yellowish with a black spot at the base.

\section{Species 6: Puntius guganio (Hamilton-Buchanan, 1822)}

Puntius guganio was originally described as Cyprinus guganio (Hamilton-Buchanan, 1822) from Brahmaputra and Yamuna River, India. A brief history of the species with special reference to Indian contributions has been given below.

1822 Cyprinus guganio Hamilton-Buchanan, Fishes of ganges: 38,392

1868 Barbus ambassis Day, Proc. Zool. Sco. Lond.: 583; Day, 1878, Fishes of India: 576, pl. 135, 1; day, 1889, Fauna Br. India, Fishes, 1:324

1878 Barbus guganio Day, Fishes of India:579; Day, 1889, fauna Br. India, Fishes, 1: 328

Type species: Cyprinus guganio Hamilton-Buchanan, 1822, Fishes of Ganges: 38, 392
Type locality: Brahmaputra and Yamuna River, India

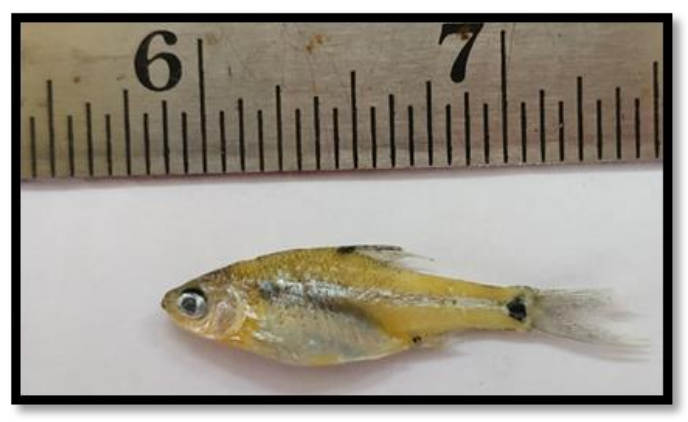

Figure 6. Puntius guganio (Hamilton-Buchanan, 1822)

Diagnosis of Species (Fig-6): Body elongate, eyes large, mouth terminal, no barbells, scale small. Lateral line is incomplete, 34-36 scales in longitudinal series. Body light greenish with a silvery band, a small black spot at base of anterior dorsal fin rays, total length: $4-6 \mathrm{~cm}$.

Fin formula: D iii 8; P i 10; V i 8; A ii 5

Ornamental Value: P. guganio has transparent body, along with silver band starting behind the operculum which has extended to the base of caudal fin, a black blotch present at the base of caudal fin another one present at the base of dorsal fin which is extended as a black stripe at the frontal part of dorsal fin; made the fish very attractive; so it can be kept as ornamental fish.

\section{Species 7: Puntius phutunio (Hamilton-Buchanan, 1822)}

Puntius phutunio was originally described as Cyprinus phutunio (Hamilton-Buchanan, 1822) from north-east Bengal, India. A brief history of the species with special reference to Indian contributions has been given below.

1822 Cyprinus phutunio Hamilton-Buchanan, Fishes of Ganges: 319,390.

1878 Barbus phutunio Day, Fishes of India: 578, pl. 145, fig. 4.

Type species: Cyprinus phutunio Hamilton-Buchanan, 1822, Fishes of Ganges: 319,390.

Type locality: Ponds of north-east Bengal

Diagnosis of Species (Fig-7): Body somewhat deep, eyes large, mouth small, no barbells. Scale large, lateral line incomplete, 18 to 24 scales in longitudinal series. Presence of three black blotches, one is behind gill-cover, second above anal fin and third as a spot on caudal peduncle, total length: $2.5-4 \mathrm{~cm}$.

Fin formula- D ii-iii 8; P i 14; V i 8; A iii 5 


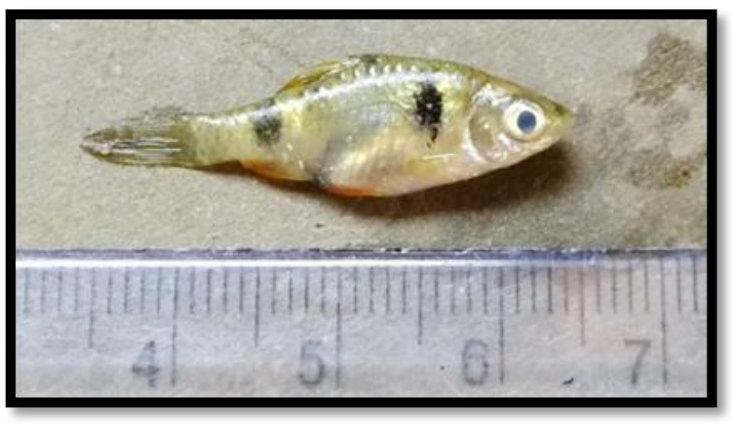

Figure 7. Puntius phutunio (Hamilton-Buchanan, 1822)

Ornamental Value: Puntius phutunio possess silvery body along with 2 black stripes appear vertically up its body which consider as ornamentally valuable. The black band is also variable number and positioning of dependent on geographical areas. Their colorful body and peaceful and interest behavior make a welcome addiction any larger community aquarium.

\section{Species 8: Puntius sarana (Hamilton-Buchanan, 1822)}

Puntius sarana was originally described as Cyprinus sarana (Hamilton-Buchanan, 1822) from west Bengal. A brief history of the species with special reference to Indian contributions has been given below.

1822 Cyprinus sarana Hamilton-Buchanan, Fishes of Ganges: 307, 388

1878 Barbus sarana Day, Fishes of india: 560, pl. 136, fig. 2; Day, 1889,Fauna Br, India, fishes, 1: 300

1981 Puntius saberi Datta and Karmakar, 1981, Bull. Zool. Surv. India, 3(3): 179, fig. 1

Type species: Cyprinus sarana Hamilton-Buchanan, 1822 Fishes of Ganges: 307, 388

Type locality: Ponds \& rivers of West Bengal

Diagnosis of Species (Fig-8): Body elongate, eyes moderate, mouth moderate, two pairs of barbells. Scale medium, lateral line complete with 29 to 34 scales. Body color is black olive silvery without any black spot, total length: $8-15 \mathrm{~cm}$.

Fin formula: D iii-iv 8; A iii 5; P i 14-17; v i 8

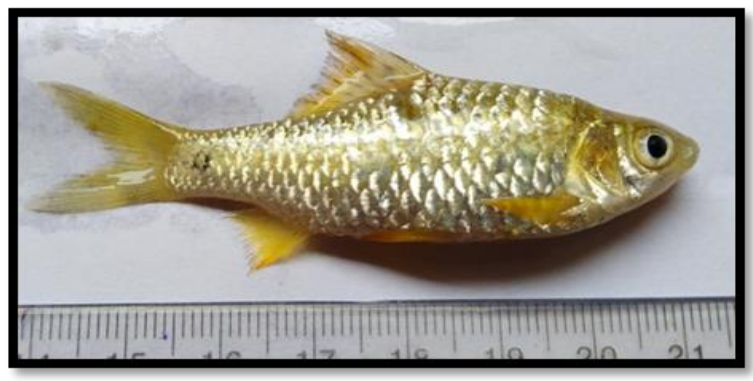

Figure 8. Puntius sarana (Hamilton-Buchanan, 1822)
Ornamental Value: The body color of Puntius sarana is olive-green to silvery with its active nature can made the species highly valuable as ornamental fish.

Species 9: Puntius sophore (Hamilton-Buchanan, 1822)

Puntius sophore was originally described as Cyprinus sophore (Hamilton-Buchanan, 1822) from pond and rivers in Gangetic provinces. A brief history of the species with special reference to Indian contributions has been given below.

1878 Barbus chrysopterus (McClelland) Day, Fishes of India: 579, pl.143, fig. 6; Day, 1889, Fauna Br. India, Fishes, 1:329.; Mirza, 1971,Biologia, 17(1): 49.

1924 Barbus annandalei Fowler, Proc. Acad. Nat. Sci. Phild., 76:87, fig. 6.

1924 Barbus carletoni Fowler, Proc. Acad. Nat. Sci. Phild., 76:89, fig. 7.

1974 Puntius sophore Menon, Special Publication No. 1. Inland Fisheries Soc., p:136.

Type species: Cyprinus sophore Hamilton, 1822, Edinburgh \& London, i-vii + 1-405.

Type locality: Pond and rivers in Gangetic provinces.

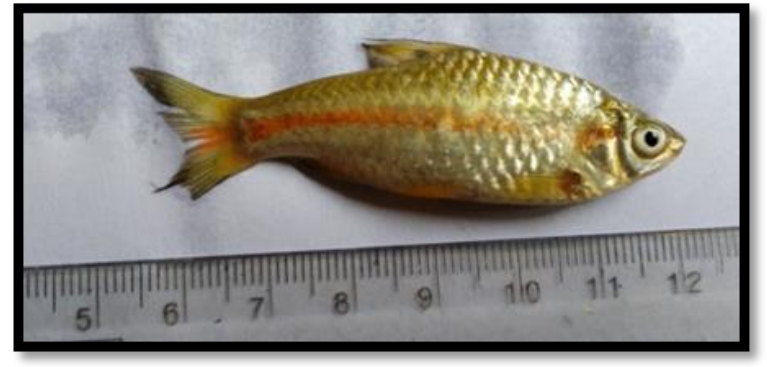

Figure 9. Puntius sophore (Hamilton-Buchanan, 1822)

Diagnosis of Species (Fig-9): Body deep and moderately compressed. Dorsal portion is more convex than ventral portion. Mouth is small and terminal. Upper jaw is slightly longer than lower jaw. Barbells are absent. Pelvic fin originated behind the origin of dorsal fin. Lateral line complete with 22- 27 scales, total length: $7-13 \mathrm{~cm}$.

Fin formula- D iii-iv 8-9; P i 14-17; V i 7-8; A iii 5.

Ornamental Value: It can consider as ornamental fish due to silvery-golden body color along with a reddish orange bands appear on the lateral side of the body. Besides these two black spots one on caudal peduncle another on the base of dorsal fin. The orange color on anal and pelvic fin and orange spot on operculum makes it really attractive and popular.

\section{Discussion}

Study on the distribution of fishes in particular 
biosphere is very important to understand the ecological significance of the species. Many factors such as altitude, water temperature, habitat type, food availability, predator and ecological barrier etc. are the determining factors for distribution of species in aqua-habitats. During the study period, we identified 9 species of the genus Puntius such as Puntius chola (Hamilton- Buchanan, 1822), Puntius ticto (Hamilton- Buchanan, 1822), Puntius terio (Hamilton- Buchanan, 1822), Puntius gelius (HamiltonBuchanan, 1822), Puntius guganio (Hamilton- Buchanan, 1822), Puntius phutunio (Hamilton- Buchanan, 1822), Puntius sarana (Hamilton- Buchanan, 1822), Puntius sophore (Hamilton- Buchanan, 1822), Puntius conchonius (Hamilton- Buchanan, 1822) from different blocks of Purba Medinipur, Paschim Medinipur \& Jhargram district of West Bengal. Puntius gelius (Hamilton-Buchanan, 1822) and Puntius guganio (Hamilton-Buchanan, 1822) has been recorded first time from the study area. All the species listed here has potentiality to be established as ornamental fish because of their body color, spot, band and attractive behavior. As per IUCN conservational status one species, namely Puntius sarana (Hamilton-Buchanan, 1822) is vulnerable and Puntius guganio (Hamilton-Buchanan, 1822) is so far regarded as not evaluated and the remaining seven species are least concern. Present study reveals that Puntius chola (Hamilton- Buchanan, 1822) and Puntius sophore (Hamilton-Buchanan, 1822) shows high abundance in the study area. Puntius terio (Hamilton- Buchanan, 1822), Puntius gelius (Hamilton- Buchanan, 1822), Puntius guganio (Hamilton- Buchanan, 1822) and Puntius sarana (Hamilton- Buchanan, 1822) shows very low abundance and needed immediate conservation or these species will be locally extinct. Therefore, present study will certainly be a land mark for future researchers and policy planners to study on the group from the study area.

\section{Acknowledgements}

Authors are very much grateful to the state DST, Govt. of West Bengal for financial support under which the present studies have been conducted.

\section{REFERENCES}

[1] Hamilton, Buchanan F (1822) An Account of the Fishes of River Ganges and its Branches. George Ramsay and Co., London. pp. Vi

[2] Hora, S.L. and Mukerjii, D.D. 1934, notes on fishes in the Indian museum, XXII. On a collection of fish from the S. Shan States and the Pegu Yomas, Burma. Rec. Indian Mus., Calcutta, 36(1), pp. 123-138.
[3] Jayaram K C (1999) The Freshwater Fishes of the Indian Region. Nerendra Publishing House, New Delhi. pp. xxvii 27.

[4] Jayaram K.C (2010) The Freshwater Fishes of Indian Region, 2nd Ed. Narendra Publications, New Delhi. pp. 119 .

[5] Kisku, et al., 2017; A cross-sectional study on water quality in relation to fish diversity of PaschimMedinipur, West Bengal, India through geoinformatics approaches, Egyptian Journal of Aquatic Research 43 (2017) 283-289.

[6] Kottelat, 1999. Nomenclature of the genera Barbodes, Cyclocheilichtys, Rasbora and Chonerhinos. (Teleostei: Cyprinidae and Teraodontidae), with comments on the definition of the first reviser. The Raffles Bull. Zool.47(2):597.

[7] Kullander, Fang (2005) Two new species of Puntius from Northern Myanmar.AmersocIcthyol. 2: 290 - 302.

[8] Kullander S O (2008) Five new species of Puntius from Myanmar (Teleostei: Cyprinidae). IchthyolExplorFresWat. 19: $59-8$

[9] Menon A.G.K., Checklist- Fresh water fishes of India. Records of Zoological Survey of India, Occasional, 175, 1-366 (1999)

[10] Moglekar H. S et al., 2017, Freshwater fish diversity of West Bengal; Journal of Entomology and Zoology Studies 2017; 5(2): 37-45

[11] Paul and Chanda, 2017, A check list of small indigenous fresh water fish fauna of undivided Paschim Medinipur, West Bengal, India, International journal of current trends in science and technology, ISSN: 0976-9730.

[12] Shantakumar M, Viswanath W (2006) Inter- relationship of Puntius Hamilton - Buchanan (cyprinidae: Cyprininae) found in Manipur, India. Zoo's Print. 21(6): 2279 - 2283.

[13] Smith, H.M. 1945. The freshwater fishes of Siam or Thailand. Bull. U. S. natn. Mus., (188): 1-622.

[14] Talwar P K, Jhingran A G (1991) Inland fishes of India and adjacent countries. Vol. I, Oxford \& IBH Publishing Co. Pvt. Ltd, New Delhi, pp. 541. 